\title{
What Is "Vintage" in IR? A Writer's Note
}

Kamila Pieczara, University of Warwick

Yong-Soo Eun, Incheon National University

\section{ABSTRACT The style of writing in international relations (IR) has evolved in recent decades. The lessons of "vintage" IR, to which we return in this article, have been largely forgotten by those writing in the discipline today. A merit will be substantial, we argue, in drawing more heavily from works by previous masters. Several lessons in style follow.}

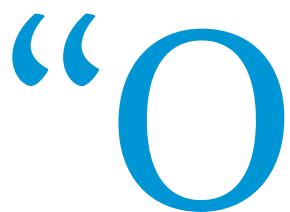

ffer your readers vigorous, concise prose in the active voice," instructs International Organization. Then it goes even further: "Rare is the manuscript that cannot be improved with tightening" ( $\mathrm{IO}$ 2011, 20203). Rare is the international relations (IR) scholar who has read those notes and applied them. Good writing, in effect, is rare. The writing advice to which $I O$ refers us is from Strunk and White (2000), Zinsser (2006), and Bernstein (1965) - the classic voices in an American battle for clear and simple writing. "An ongoing battle," we could say, if "ongoing" was not on their list for possible deletions (Strunk and White 2000, 54). That "too often our work does not attract the readership that it deserves" (Sigelman 2006, 6), suggests that clear and simple writing is an issue for political scientists more broadly.

This simplicity is more than a matter of style; it has to do with deeper values. "Rich, ornate prose is hard to digest, generally unwholesome, and sometimes nauseating" (Strunk and White 2000, 72). Economy and vigor do not seem much to be on the editors' agenda, not least as working criterion for articles' acceptance. The IO's call represents rather an ideal, the clarity of thought and expression we have lost on the way. Like in a timeless classic, here lies its austere beauty: "Vigorous writing is concise. A sentence should contain no unnecessary words, a paragraph no unnecessary sentences, for the same reason that a drawing should have no unnecessary lines and a machine no unnecessary parts" (Strunk and White 2000, 23).

Merriam-Webster Dictionary defines vintage as "of old, recognized, and enduring interest, importance, or quality." What is "vintage" should interest us, for we have distanced ourselves from previous masters. And IR foundations are shaky if it forgets a vast expanse of scholarship from earlier periods. Finally, there is sheer bafflement at how much the style of writing has changed since the 1950 or or 1960 s. Pursuing new and ever more complicated concepts, we have lost touch with an agenda of true value: clear writing following from clear thinking. In 1979 when Kenneth Waltz published Theory of International Politics (1979), IR lost its inno-

Kamila Pieczara is a PhD candidate in politics and international studies at the University of Warwick, where she studies international relations and Asia. Her hobby is studying style sheets of journals. She can be reached at k.pieczara@warwick.ac.uk.

Yong-Soo Eun is assistant professor of political science and international studies at the Incheon National University. He is also interested in art and design, especially the work of Anish Kapoor. He can be reached at yseun@incheon.ac.kr. cence. The concepts that Waltz introduced have been for IR a scientific corset. ${ }^{2}$ Nothing is to be lost from the discovery of this difference.

In the search for purity of expression and lasting value, we set out on a quest for vintage IR. The exhortations for vigorous writing and "tightening" indeed sound vintage at a time when IR authors do not shun experimenting with too many -zations: "multilateralization," "institutionalization," and "securitization" spring to mind. In an era of sentences 40 to 50 words long, brevity is not expected to stand for successful scholarship. But we maintain that brevity is more than measuring sentences with a ruler. A clear argument will naturally lead to a sentence of appropriate length. An encounter with confounded presentation, in turn, is often an encounter with an argument less than clear. A potential for healing lies in the austere beauty of vintage IR, always there for us to rediscover and admire.

\section{SHORT LESSONS IN VINTAGE IR}

Looking at the assigned reading lists in the top 10 American IR departments (Biersteker 2009), one encounters imbalances that have seen the light of day. These are primarily: gender, national base, and theoretical orientation, which means that a male, based in the United States, rational-positivist scholar is the most "expected" author of a course material. What has received less attention is the average year of this material's publication: across the 10 departments it is 1987 , where the University of Chicago stands out as "a place where classics and the great books are still taught," but at Harvard the average date of publication is 1993, and at Princeton it is 2001! (Biersteker 2009, 319-20). The need to rediscover is apparent.

Looking up references only since 1979 is not a healthy convention for a discipline as self-conscious and fragile as IR. The discipline, after all, did not emerge in $1979 .{ }^{3}$ Post-1979 IR is so heavily constructed around the Waltzian concepts, even if to criticize them, that we feel perhaps estranged with the writings from before that period. Works prior to 1979 are full of metaphors: "Whether we realize it or not, we are still swimming in a sea of naiveté" (Sartori 1970, 1033). Then the famous burning house metaphor is in Arnold Wolfers's Discord and Collaboration. "Imagine a number of individuals, varying widely in their predispositions, who find themselves inside a house on fire"; a fire being a "threat to national survival" (Wolfers 1962,13-14). The metaphor continues: "In international politics, the house is not always, nor everywhere on fire 
although the temperature may not be comfortable, even under the best of circumstances!" (1962, 15). Consider also Hoffmann (1959), another author of the period: "Theories of international relations are like planes flying at different altitudes and in different directions" (348). And not everybody knows to use such metaphors. But everybody knows to learn IR jargon, a convenient substitute for seas, fires, and planes flying in rather "vintage" IR.

Vintage is a style, but beneath that style is a vein of vigor and courage, virtually unknown to us now. Our suspicion is that current scholarship is running at a lower depth. Less engaged and less committed, it is, in effect, less courageous and less clear. We have shut ourselves out from values: not "constructivist" ideas or "normative" agendas, but values at their most basic, like pursuing a program of worth. The most memorable vintage pieces in IR ing" the reader to read on (Zinsser 2006, 54). "In the first place", "secondly", and "thirdly" nicely follow.

A look at contemporary articles is sufficient to make a oneparagraph introduction indeed feel vintage. It is an act of rare courage to attempt it-and send it out. Such an act of courage is not a statement of laziness. Yet, this mistaken belief underlies a tendency for never-ending "leads." What a fresh breeze it would be to find more compact introductions in today's writing.

\section{ELMAN (1996)}

Strunk and White warned: "Do not overwrite"; if you do, "you will have to compensate for it by a show of vigor, and by writing something as meritorious as the Song of Songs, which is Salomon's" $(2000,72)$. What is an extra show of vigor? Consider

\section{The most memorable vintage pieces in IR operate on a deeper current; the simple and clear in vintage IR stem from values and courage, audacity and intent. In the finished product, it is recognized as strength and vigor, with certain tightness.}

operate on a deeper current; the simple and clear in vintage IR stem from values and courage, audacity and intent. In the finished product, it is recognized as strength and vigor, with certain tightness. Compare "I believe in God" with "Among other important things, I think that I believe in a power, or person, known as God." You should see it now: muddled and indecisive thinkers are on a straight path to a weak sentence. Vintage IR, at its core, is about courage to say the truth, and all the rest follows from it.

Therefore, at a time when we are bored with what we do, talking about "progress in IR" is useless. To have some progress, we should instead cast off the clutter that keeps us from moving ahead. Once the clutter is out from our sentences, our thinking becomes clearer too. Let us pass, in other words, the Occam's razor along our words, sentences, paragraphs, and whole articles. To save IR from a boredom sentence, we have nothing to lose from introducing conscious changes. Like a student of octopuses, an IR scholar will do well to follow the rule: "Just because you're dealing with a scholarly discipline that's usually reported in a style of dry pedantry is no reason why you shouldn't write in good fresh English" (Zinsser 2006, 157). By starting to write more interestingly about what interests us most, we will draw closer to men and women who believed in the value of their work as IR scholars.

We continue with a few lessons from vintage IR and its younger echoes.

\section{HOFFMANN (1959)}

Perhaps the most striking feature of the forgotten era in IR writing is a brief introduction. What has motivated us in the first place to write this article was the introduction in Hoffmann (1959). In half a page, it comprises setting of the stage with outlining of the structure. Rather than introduction, it might be called a "lead," the very device that journalists have mastered but political scientists have not been trained to "get right" (Sigelman 2006, 6). The message for which the majority of scholars would need a separate paragraph, Hoffmann accomplishes in one single sentence. The beginning of the article, for instance, reads: "It has become customary to begin a discussion of the nature and present state of the discipline with a number of complaints" (346), in this way "hook-
Elman (1996), a gold mine for those seeking writing lessons in IR. This is an article comprising a textbook: the paper could be with little extra effort elaborated into one, as it cuts across major debates in IR.

We forgive Elman's (1996) overwriting, for he pursues from the beginning to the end his one main objective. The effect of focus is highlighted by a structure of symmetry; we refer to it as a structure of the "clip." The paper ties the conclusion back to the introduction with the same metaphor; Elman uses a metaphor of a race, asking if the neorealist-theory "horse" is suited for the "race" of explaining foreign policy. In the beginning, he writes:

There is an old racing maxim that every horse is suited to a particular course, and that there are some tracks where they simply cannot perform. The same kind of claim is often made in the international relations field, most notably that neorealist theories cannot be used as theories of foreign policy $(1996,7)$.

Then, he ties the conclusion back to this original puzzle: "This article establishes that the neorealist horse can run the foreignpolicy course" $(1996,48)$. The author's control emanates from this structure.

Admirable in Elman's piece is also the parsimonious introduction of quotations. Instead of usual "X said" and "Y asserted", and "Z convincingly argued," Elman uses the much underappreciated colon:

"The only state which has nothing to fear is the hegemon:

The greater the military advantage one state has over other states, the more secure it is. Every state would like to be the most formidable military power in the ...." (a longer quotation follows). Elman (1996, 27), quoting Mearsheimer (1994, 11-12).

Then, no colon is possible and even more parsimonious. Compare in the text that follows:

"Walt argues that Kaufman's

error arises in part from confusion about the definition of balancing itself. For Kaufman, the British and French failure to take military 
action during the Rhineland crisis and their decision to appease...." (a longer quotation follows). Elman (1996, 45), quoting Walt (1992, 454).

What we would generally get is: "Mearsheimer says that ...", "Kaufmann argues that ..."-a pattern of "this and this says such and such," cluttering a sentence and anaesthetizing readers, making of them "the writer's victims" (Roberts 2009). The point is this: vary the way that quotations are introduced, always favoring the parsimonious way. A parsimonious introduction of quotations, in addition, is an indication that a quotation serves its purpose best where it is; if a quotation cannot be introduced parsimoniously, it may suggest that it can be omitted without a loss to the argument's strength.

Where a shorter quotation will do, it should be favored, especially when the quotation's message is vital.

An indented quotation in small print is likely to be scanned by the reader.

The writer can counteract this by introducing a quotation in the text, thus ensuring that it will be treated just like the author's writing.

\section{WEVER (2010)}

Strunk and White advise that the proper place for what is to be made most prominent is the end (Strunk and White 2000, 33). Wæver (2010) finishes paragraphs with a short and memorable some point, all IR scholars will talk about "the real world." But few will come up with something as refreshing as "the real world of any one moment" (Eun 2012, abstract; emphasis added). ${ }^{4}$

The care for the reader's sense of beauty, therefore, should sometimes take precedence over a "ten-center" word (Strunk and White 2000, 76-77); the keyword, here, is sometimes. Those who are learning to write in IR should start from the clearest and the simplest, mastering their craft, which is not literature but social science. If the writer's first objective is to dazzle, it will surely come at the price of building disciplinary knowledge. Only when the tools are learned and craft is mastered, a style will emerge against the argument in its bare beauty. Knowledge must shine first, writingsecond. Both take a lot of time and effort.

\section{LESSONS THAT FOLLOW}

Of note is the length criterion or much dreaded "word count." Fearing overwriting, writers, in haste, delete and shorten. The other side of the equation is generally forgotten. Not every argument is worth a 10,00o-word pursuit. Writers' propensity to overwrite needs to be curbed, yet does this mean that every article must be exactly 10,000 words long? Here, we face a question of implied laziness. Most authors would shun submitting an article of "only" 6,000 or 7,000 words, in the faith that it will look underdeveloped. "Assume that you are the writer sitting down to write. You think your article must be of a certain length or it won't seem important" (Zinsser 2006, 19). Rather than the present fixation with

\section{"An occasional short sentence can carry a tremendous punch. It stays in the reader's ear" (Zinsser 2006, 36).}

sentence and does so to stunning effect: "IR is a discipline within a discipline" (302) or "It is our progress" (316; emphasis original).

That a simple sentence can be powerful even in mid-paragraph is shown here:

However, the journals are mainly defined, structured, and to a certain extent controlled by theorists. You become a star only by doing theory. The highest citation index scores all belong to theorists ... Wæver (2010, 306).

"An occasional short sentence can carry a tremendous punch. It stays in the reader's ear" (Zinsser 2006, 36).

\section{A WORD OF CAUTION}

English is not only the American language just as parsimony is not everybody's second skin. Latin expressions, what their enemies Strunk and White should appreciate (see "avoid fancy words" and "avoid foreign languages," Strunk and White 2000, 76-78, 81), tend to be short and to the point, perhaps apart from per se, the IR scholars' favorite. British and continental scholars in particular have taken to Latin expressions, breaking monotonous, at times, jargon. We like to see a Latin expression where it is more gracious than plain English, from "reasons for this renovatio ab imis" (Sartori 1970, 1034), to "process oriented modus operandi" (Higgott 1997, 176).

Brevity and omitting needless words, the core of Strunk and White's legacy, is the default choice. A departure from "deleting" is worth considering when introducing common expressions. At hitting the word limit, tailoring the length more accurately to the desired objective would serve scholarship better. This is the first scholarly practice worth rethinking.

Second comes sounding scientific. Using the example of Orwell's rewriting of a Bible's passage, Strunk showed how a text will look after it is deprived of its vigor (Strunk and White 2000, 22-23). A rare opportunity to see how it works in IR is in comparing Cha (1999) and (2000). In the book we read:

At the 1988 Olympic Games in Seoul the overtones of the cold war were clear. The United States and Soviet Union had boycotted successive Olympic Games in Moscow and Los Angeles in 1980 and 1984. As a result, American and Soviet spectators and participants at the Seoul Games dutifully cheered the athletes and teams from their respective geopolitical spheres of influence. However, a peculiar sight astonished some observers of the host Koreans that year: in an event pitting the Soviet Union against Japan, Koreans cheered their Communist adversaries, not their cold-war partners (Cha 1999, 1).

One year later, a similar point has been put differently in the article: "Realism offers an alternative interpretation of JapanKorea outcomes" (2000, 262). This sounds scientific indeed, but it is deprived of the vigor that the book has. And this is not an attack on Cha (2000) but rather an intense questioning of "scientifism" as a scholarly practice. "A first step in changing professional practice is to stop replicating that practice in our scholarly lives" (Lake 2011, 472). 


\section{CONCLUSION}

Clarity and simplicity, contrary to the popular belief, are not easy pursuits. Nothing is as "natural" in clear writing that would not require extreme effort or self-discipline. To encourage scholars to pursue them, such efforts should be rewarded. The reward structure in IR leads us straight to IR journals. The change should then come from these silent teachers for new generations of IR scholars. Students in IR learn to write from reading the best examples. What are the best examples is decided within journals. What journals publish today largely determines what will be submitted tomorrow.

Can we imagine how IR scholarship would look like if "economy" from IO's guidelines $(2011,203)$ was a working criterion for acceptance? If we cannot imagine this, it is because we have embraced complexity in content, compounded by hypercomplexity in presentation, as a hallmark of superior knowledge, indeed the endeavor to be rewarded. An astringent solution to the many excesses of today's scholarship can be found in vintage IR. Let us then have the courage to return to the classics that never lose relevance in quality of content and presentation, echoing "the halloos that bear repeating" (Strunk and White 2000, 70).

\section{NOTES}

1. Strunk and White (2000) was first published as a co-authored version in 1959 and is based on Strunk (1918). Zinsser (2006) was first published in 1976, and the version we use is the zoth anniversary edition.

2. See Kratochwil (1993): “The academic exponents of 'realism' had prided themselves on giving greater precision, depth and, above all, scientific respectability, to the fuzzy realism practiced or preached ..." (64).

3. IR, as a separate discipline, emerged in the aftermath of World War I (Hollis and Smith 1990, 16). What interests us primarily here, however, is that IR does have a tradition longer than thirty years!

4. This quotation was chosen by Kamila Pieczara.

\section{REFEREN CES}

Bernstein, Theodore M. 1965. The Careful Writer: A Modern Guide to English Usage. New York: The Free Press.

Biersteker, Thomas J. 2009. "The Parochialism of Hegemony: Challenges for 'American' International Relations." In International Relations Scholarship Around the World, eds. Arlene B. Tickner and Ole Wæver. London: Routledge.
Cha, Victor D. 1999. Alignment despite Antagonism: The United States-Korea-Japan Security Triangle. Stanford, CA: Stanford University Press.

. 200o. "Abandonment, Entrapment, and Neoclassical Realism in Asia: The United States, Japan, and Korea." International Studies Quarterly 44 (2): 261-91.

Elman, Colin. 1996. "Horses for Courses: Why Not Neorealist Theories of Foreign Policy?" Security Studies 6 (1): 7-53.

Eun, Yong-Soo. 2012. "Why and How Should We Go for a Multicausal Analysis in the Study of Foreign Policy? (Meta-) Theoretical Rationales and Methodological Rules." Review of International Studies 38 (4): 763-83.

Higgott, Richard. 1997. "De Facto and De Jure Regionalism: The Double Discourse of Regionalism in the Asia Pacific." Global Society 11 (2): 165-83.

Hoffmann, Stanley H. 1959. "International Relations: The Long Road to Theory." World Politics 11 (3): 346-77.

Hollis, Martin, and Steve Smith. 1990. Explaining and Understanding International Relations. Oxford: Clarendon Press.

International Organization (IO). 2011. "Guidelines for Contributors." International Organization 65 (1): 201-05.

Kratochwil, Friedrich. 1993. "The Embarrassment of Changes: Neorealism as the Science of Realpolitik without Politics." Review of International Studies 19 (1): 63-8o.

Lake, David A. 2011. "Why 'isms' Are Evil: Theory, Epistemology, and Academic Sects as Impediments to Understanding and Progress." International Studies Quarterly 55 (2): 465-80.

Mearsheimer, John J. 1994. "The False Promise of International Institutions." International Security 19 (3):5-49.

Roberts, Sam. 2009. “The 'Elements of Style' Turns 50.” New York Times, April 22.

Sartori, Giovanni. 1970. "Concept Misformation in Comparative Politics." American Political Science Review LXIV (4): 1033-53.

Sigelman, Lee. 2006. “Foreword.” In Style Manual for Political Science. American Political Science Association. http://www.apsanet.org/media/PDFs /Publications/APSAStyleManual2006.pdf (accessed February 7, 2013).

Strunk, William Jr. 1918. The Elements of Style. Ithaca, NY: W. P. Humphrey.

Strunk, William Jr., and E. B. White. 200o. The Elements of Style. 4 th ed. Needham Heights, MA: Pearson/Longman.

Wæver, Ole. 2010. “Still a Discipline After All These Debates?” In International Relations Theories: Discipline and Diversity, eds. Tim Dunne, Milja Kurki, and Steve Smith, 2nd ed. Oxford: Oxford University Press.

Walt, Stephen M. 1992. "Alliances, Threats, and U.S. Grand Strategy: A Reply to Kaufmann and Labs." Security Studies 1 (3): 448-82.

Waltz, Kenneth N. 1979. Theory of International Politics. Reading, MA: Addison-Wesley.

Wolfers, Arnold. 1962. Discord and Collaboration: Essays on International Politics. Baltimore: Johns Hopkins University Press.

Zinsser, William. 2006. On Writing Well: The Classic Guide to Writing Nonfiction. 7 th ed. New York: Collins. 